\title{
RESILIENCE AS A FORM OF CONTESTATION IN LANGSTON HUGHES' EARLY POETRY
}

\author{
LA RESILIENCIA COMO FORMA \\ DE CONTESTACIÓN EN LA POESÍA \\ TEMPRANA DE LANGSTON HUGHES
}

\author{
ALBA FERNÁNDEZ ALONSO \\ Universidad de Burgos \\ albafa@ubu.es \\ MARÍA AMOR BARROS DEL RÍO \\ Universidad de Burgos \\ abarros@ubu.es
}

\begin{abstract}
The history of the African American community has been inexorably bound to the concepts of oppression, downgrading, racism, hatred and trauma. Although the association between racism and concomitant negative psychological outcome has been widely assessed, little work has been done to study the role of literature as a cultural means to promote resilience among this oppressed group. Langston Hughes (1902-1967) stands out as a novelist, poet and playwright, and is one of the primary contributors to the Harlem Renaissance movement. Following the framework of theories of resilience, this article analyses the representation of adversity and positive adaptation in Langston Hughes's early stage poetry, and assesses his contribution to resilience among the African American people at a time of hardship and oppression.
\end{abstract}

Keywords: Langston Hughes, African American poetry, resilience, Harlem Renaissance.

\section{Resumen}

La historia de la comunidad afroamericana ha estado inexorablemente vinculada a los conceptos de opresión, degradación, racismo, odio y trauma. Aunque la 


\section{Alba Fernández Alonso y María Amor Barros del Río}

relación que hay entre el racismo y los efectos psicológicos negativos se ha estudiado ampliamente, aún son escasos los trabajos que analizan el papel de la literatura como medio cultural para promover la resiliencia entre los grupos oprimidos. Langston Hughes (1902-1967), destacado novelista, poeta y dramaturgo, es uno de los principales contribuyentes al movimiento conocido como Renacimiento de Harlem. Siguiendo el marco de las teorías de la resiliencia, este artículo analiza la representación de la adversidad y la adaptación positiva en la poesía temprana de Langston Hughes, y evalúa su contribución a la resiliencia de la población afroamericana en un momento de grandes dificultades y opresión.

Palabras clave: Langston Hughes, poesía afroamericana, resiliencia, Renacimiento de Harlem.

\section{Connecting Psychological Resilience and African Americans}

The African American people have for long experienced oppression, racism and trauma. The treatment of the former slave as a mere commodity, the broken promise of the American dream, and the racial subjugation translated into the annihilation of basic human rights. The traumatic effects of the African American struggle are still visible in the current situation of the African American community in the United States (Bonilla-Silva 2003; Feagin 2010). The association between racism and concomitant negative psychological outcome has been widely assessed in order to demonstrate the extent to which African Americans have been increasingly at risk from exposure to stressful life events (Karlsen and Nazroo 2002; McCord and Freeman 1990; Thoits 1991). That sustained trauma has been defined as "a reaction to profoundly injurious events and situations in the real world and, indeed, to a world in which people are routinely wounded" (Burstow 2003: 1302). Naturally, it has had a direct and grievous impact on African Americans' psychological and physiological health with effects ranging from the development of somatic complaints, negative affect, depression and anxiety (Bowen-Reid and Harrel 2002) to post-trauma responses (Bryant-Davis and Ocampo 2005). Added to this, chronic exposure to racism has aggravated the psychological and physiological responses among the African American community (Kwate et al. 2003; Williams et al. 2003).

Notwithstanding the evidence, many African Americans have not succumbed to psychological stress. Instead, they have shown psychological resilience. According to Rutter, this term is an "interactive concept that refers to a relative resistance to environmental risk experiences or the overcoming of stress or adversity" (2006: 1). 
Furthermore, this author defines psychological resilience as a concept "concerned with the combination of serious risk experiences and a relatively positive psychological outcome despite those experiences" (2006: 2). It should be noted that resilience is a process that changes over time across the individual's lifespan and from situation to situation. Therefore, resilience is also the changing capacity of reaction an individual can show to the same stressor over his or her life (Davydov et al. 2010). But for resilience to occur, two pivotal concepts must occur, namely, adversity and positive adaptation (Luthar 2006; Luthar and Cicchetti 2000). The term adversity has been defined as any hardship and suffering connected to difficulty, misfortune and trauma (Jackson et al. 2007), while positive adaptation has been considered as "behaviorally manifested social competence, or success at meeting stage-salient developmental tasks" (Luthar and Cicchetti 2000: 858). In fact, the concept of resilience is correlated with general protective factors, not necessarily associated with issues of race. These factors are defined as "influences that modify, ameliorate, or alter a person's response to some environmental hazard that predisposes to a maladaptative outcome" (Rutter 1985: 600). Thus, optimism, curiosity, high levels of energy and the ability to detach and conceptualize problems (Block and Block 1980) are some of those factors that together with hardiness (Bonanno 2004), positive affect (Zautra et al. 2005), self-efficacy (Gu and Day 2007), self-esteem (Kidd and Shahar 2008), positive emotions (Tugade and Fredrickson 2004), spirituality (Bogar and Hulse-Killacky 2006) and extraversion (Campbell-Sills et al. 2006), constitute the universe that protects the individual from potentially harming issues. ${ }^{l}$

Research demonstrates that empirical experience with traumatic stressors promotes the implementation of mechanisms that display resilience (Breslau et al. 2006). That would explain why African Americans and other minority ethnic groups show statistically more resilience than the average white American individual. Additionally, Clauss-Ehlers (2008) incorporates the term culture to the definition of resilience and considers cultural factors as the centrepiece to understand resilient processes. Following this trend, a growing body of research suggests that certain aspects present in African American culture may have had a protective function and thus contributed to the individual's ability to overcome distress from racial discrimination (Miller 1999; Miller and MacIntosh 1999; Utsey et al. 2007). Racial socialization and social support networks are two empirically demonstrated aspects of African American culture used as defensive devices when facing psychological distress. Also messages that promote cultural pride, heritage and history contribute positively to the promotion of resilience and have commonly been associated with improved academic achievement, racial identity development and positive cognitive and socioemotional outcome (Caughy et al. 2002). 


\section{The Foundations of the Harlem Renaissance and the Consolidation of a New Movement}

Past centuries have witnessed the atrocities committed in the name of white supremacy against the African American community. This racial dichotomy has always been present in the United States in spite of various attempts at improving the situation. Under the principle "separate but equal", the Jim Crow laws enforced racial segregation in public places between the end of Reconstruction in 1877 and the passing of the Civil Rights Act signed by President Lyndon B. Johnson in 1964. The mass protests against this de jure segregation reached its peak in the mid-1950s under the American Civil Rights Movement. This movement, to which many whites also committed, marked a milestone in the history of the United States not only because it meant a quest for equal rights legislation, but also because it served to convey an endeavour to face the de facto oppression and injustice experienced by blacks on political, cultural and social grounds. It became an unprecedented courageous march for freedom and racial equality, and it inspired the generations to come in their search for the status and support they deserved.

World War I had been a "kind of puberty rite for peoples the world over" (Huggins 2007: 83). These feelings of empowerment, independence and bold forcefulness inspired African Americans to find the origin of a culture they had inherited but that seemed, in Langston Hughes's words, "so long, so far away" (Rampersad 1995: 129). Furthermore, these feelings were to lay the foundations of the New Negro, which was a result of this race-building period (Huggins 2007). According to Huggins, such a quest for race reformulation was mainly based on the Americanization process African Americans had been subject to since their arrival in the Americas: "So, black men yearned, as American provincials, to find meaning and identity in Africa; their frustration was a measure of their Americanization" (2007: 83). This annihilation of cultural foundations combined with the alienation of the individual, the enslavement and violence, was the spark that set off the renouncement of the principles imposed by the white American society of the time. The materialization of a new redefined identity was to be founded upon an enriched folk culture whose spiritual freedom jarred moralizing conventions and codes of the American society. This attempt to rethink and redefine race, combined with the dreadful situation of blacks, constituted a truly heroic task to undertake. Thus, it can be affirmed that the struggle of the African American people took the form of positive adaptation strategies to alienation and violence through the gestation of a new movement. Feelings of empowerment, race, pride and reformulation converged to embody a determined defence of blackness through a massive cultural production that materialized in the Harlem Renaissance. The 
prospective consolidation of the Negro as a first-class citizen needed the reaffirmation of a rooted past and the appraisal of the race. Black intellectuals, poets and writers came to the fore advocating the reformulation of a new identity, the New Negro, that would emphasize its worth and its culturally enriched past. This movement emerged in the early years of the 1920s in Harlem, a district of New York City occupying a large part of northern Manhattan. This area would later become the mecca of the Negro artist and epitomize the artistic movement of the so-called Harlem Renaissance.

\section{Langston Hughes and the Harlem Renaissance}

Undoubtedly, the role played by the Harlem Renaissance in the reconstruction of African American sense of identity was essential. This artistic movement became a shelter from the cultural trauma this oppressed group had been experiencing for too long. Since cultural trauma involves "a dramatic loss of identity and meaning, a tear in the social fabric, affecting a group of people that has achieved some degree of cohesion" (Eyerman 2001: 2), the Harlem Renaissance movement succeeded in putting a collective memory into words, transforming negative into positive and reconstructing the African sense of identity.

Amidst the intellectuals and writers of the time, Langston Hughes (1902-1967) stands out as a poet, novelist and playwright, and particularly as one of the primary contributors to the Harlem Renaissance. Hughes succeeded in speaking his mind by portraying a many-sided picture of the African American at a time when America was designed and reserved for whites. His personal evolution and refinement into a poet of the people goes hand in hand with the progression of the historical and sociopolitical events impinging on the African American of the time, to whom he predominantly showed a positive and optimistic approach in his literary contributions. ${ }^{2}$ By the same token, the tribulations reflected in his work were generally used as an opportunity to find hope in hardship. He did not let bitter experiences defeat him. On the contrary, the struggle, inner strength and courage he cultivated are also detectable in his prose, poetry, newspaper columns, autobiography and fiction, thus demonstrating a high degree of resilience. The so-called leading voice of the Harlem Renaissance had a strong sense of race pride. His production focuses on the ordinary lives of the black community contextualized under the shadow of racism, oppression and injustice. Likewise, moral, political and social issues are present in his work where he always adopted a sociopolitical stand translated into a fierce defence of dignity and humanity. His social activist profile emanated from the admiration he professed towards authors of the American literary tradition, among whom we find Harriet Beecher Stowe, whose 


\section{Alba Fernández Alonso y María Amor Barros del Río}

novel Uncle Tom's Cabin (1852) he described as “a moral battle cry" (Rampersad 2002: 203). Hughes's development as a social poet was undoubtedly inspired also by Whitman, Twain and Du Bois, whose humanity and sense of freedom he incorporated into his art (Tracy 2004).

But Hughes's aesthetics was also endowed with clear features of the folk heritage he so much worshipped. The essence of the spirituals is undeniably linked to the essence of the black race and its history of suffering, sorrow and oppression (Chinitz 1997). Hughes's attempt to use the oral tradition as a template for the African American poetry constitutes a hallmark in his early stage (Onwuchekwa 1977). The emotional power of the folk materials is incorporated in a legacy of poems aimed at capturing the imagination of the ordinary citizen and expressed in their own vernacular. This shows that cultural factors are central to understanding how resilience shows in Langston Hughes's work.

The way his personal life and the course of history influenced his production would inspire his ideological transformation. Particularly relevant were the Jim Crow laws as forms of subjugation which he contested through an appeal to cultural pride and racial awareness, especially during his early years as a poet and the attempts at the Americanization of the Negro in the 1920s. At this time, Huggins averts, “the black man's metamorphosis was assumed by everyone, and thoughtful people knew the change would have a profound effect not only on the American Negro but on American culture, and, indeed, the multi-colored world itself" (2007: 56). African Americans were then in a position to reaffirm themselves as first-class citizens by rejecting former, fictional stereotypes and exercising their full rights as free people. Through the rediscovery and redefinement of their culture, and the defence of their values and race, they would contribute to the development of a new budding but sceptical American civilization. This new identity, still to be negotiated, inevitably presented the African American with a dilemma that implied coming to terms with a racist society that would reject any contribution of value based on race-building and that was by no means willing to welcome the Negro in complex urban life. W.E.B Du Bois, an author much admired by Hughes, had already shed some light on this matter in 1903 in his theory of double-consciousness in The Souls of Black Folk, by stating the following:

In this merging he wishes neither of other selves to be lost. He would not Africanize America, for America has too much to teach the world and Africa. He would not bleach his Negro soul in a flood of white Americanism, for he knows that the Negro blood has a message for the world. (Du Bois, Washington and Johnson 1965: 215)

It was indeed this need to show to the white world the talents and worthiness of a well-grounded culture that set Langston Hughes on his quest for race appraisal through his cultural production between 1920 and 1930. Despite the reawakening 
of racism through the new Ku Klux Klan, this period was key to the history of the African American in the United Sates. Accordingly, Hughes's initial period as a poet mirrors different forms of resilience incorporated in his art. In the words of Alain Locke, one of the catalysts of the New Negro Movement, this new American Negro was "acting as the advance-guard of the African peoples in their contact with the Twentieth Century civilization [...] and had the sense of a mission of rehabilitating the race in world esteem from that loss of prestige for which the fate and conditions of slavery ${ }^{3}$ have so largely been responsible" (1997: 14).

\section{Langston Hughes's Early Literary Contributions}

Hughes's repertoire all through the 1920s shows an absolute pride in his race despite racial tensions, and an unshakeably positive attitude no matter the effect his work might have on a white audience. In his essay "The Negro Artist and the Racial Mountain", published in The Nation in 1926, Hughes gives proof of how positive adaptation is embraced when facing adversity, a stance that would serve as a basis for his literary production:

We younger Negro artists who create now intend to express our individual darkskinned selves without fear or shame. If white people are pleased we are glad. If they are not, it doesn't matter. We know we are beautiful. And ugly too. The tom-tom cries and the tom-tom laughs. If colored people are pleased we are glad. If they are not, their displeasure doesn't matter either. We build our temples for tomorrow, strong as we know how, and we stand on top of the mountain, free within ourselves. (Hughes 1926: 694)

During the $20 \mathrm{~s}$, the reader encounters a series of poems that celebrate difference. They constitute a landmark by looking on the bright side when modern America in the making was not yet willing to embrace the principles and morals that Hughes advocated for. In this sense, his poetry has been qualified as "a fundamentally new kind of verse, one that told of the joys and sorrows, the trials and triumphs, of ordinary black folk, in the language of their typical speech" (Rampersad 1995: 4). This gives Langston Hughes' work scope and consistency enough for it to offer a corpus for research upon resilience. During this early period (in 1921), before the poet makes a major ideological turn to the left after his trip to Haiti in 1931, Hughes enrols at Columbia University. He withdraws one year later and starts laying the foundations that will so uniquely characterize his art. His failure to visit his father in Mexico in 1922 forms one of the most crucial episodes in Hughes's first autobiographical work, The Big Sea (1940), where he confesses: "My father hated Negroes. I think he hated himself, too, for being a Negro [...] and when I thought of my father I got sicker and sicker. I hated my father" (1993: 40-49). 


\section{Alba Fernández Alonso y María Amor Barros del Río}

Later, through his voyage to the west coast of Africa in 1923, he discovers the real meaning of blackness, as he writes: “[...] my Africa, Motherland of Negro peoples! And me a Negro!, Africa!” (1993: 10). But it is not until 1925 that Hughes establishes first contact with one of the white patrons of the Harlem Renaissance, Carl Van Vechten, and other writers and intellectuals such as Alain Locke, Zora Neale Hurston and Wallace Thurman, who so passionately commit to the same cause and help him channel his literary success.

All in all, the decade between 1920 and 1930 represents the awakening of his career as a celebrated artist, materialized in an arsenal of poetry that embodies a celebration of difference and an appraisal of race from a positive and resilient perspective. At this point, his work is not yet sullied by the pessimism and sadness later reflected in his art as a result of the injustice and helplessness undergone by African Americans in the United States. On the contrary, this decade encompasses a firm determination, namely, "to explain and illuminate the Negro condition in America and obliquely that of all human kind" (Rampersad 2002: 418). This aspiration would imbue his poetry for more than forty years.

\section{Exploring Hughes's Poetry of Resilience}

Following the theoretical pathways that resilience studies takes, this analysis focuses on Langston Hughes' early poetry (1920-1930). During this period, he published two collections of poems, The Weary Blues (1926) and Fine Clothes to the Jew (1927). And then, some of the poems included in The Negro Mother and Other Dramatic Recitations (1931), Dear Lovely Death (1931) and The Dream Keeper and Other Poems (1932) had been conceived and published elsewhere during this early stage. The poems under study here were later collected and edited by scholar, literary and cultural critic Arnold Rampersad in The Collected Poems of Langston Hughes (1995), a volume dedicated to Hughes's fruitful career as a poet from 1920, the moment when the desire to become a writer is born, to his death in 1967 . In the interest of clarity, all references to Langston Hughes's poems will be to this comprehensive volume. In order to detect both adversity and positive adaptation, the two factors required for resilience to emerge, particular attention is paid to his representation of the features of adversity in the form of racial discrimination, and the hopes and dreams that allow resistance and hope. These can be traced in the tone of speech, the use of the voice and the semantic fields used to convey rage and hope, tradition and change, when calling upon the Negro community to show resilience.

The assertive tone heard in most poems is achieved by the use of the present and imperative tenses and avoiding the conditional forms. This way Hughes voices 
the familiar situation of oppression but also expresses his unshakeable hope for a different future. Particularly meaningful is "Mother to Son", first published in Crisis in 1922, where the painful experience of prior generations is voiced through the mother figure speaking. Strategies of resistance are evidenced in the use of the first person speaker who explains the historical struggle his people had to endure. Here, the mother embodies trust and hope. Her direct illocutionary act is both colloquial and demanding and positions the author as a witness of a situation too real to be questioned. Through the metaphor of life as "no crystal stair", tacks, splinters and boards torn up symbolize the hardship that has been overcome:

For I'se still goin', honey,

I'se still climbin'. (Rampersad 1995: 30)

Here, the past struggle and the triumphant tenacity that the mother figure embodies justify the imperative verses: "Don't you set down on the steps" and "Don't you fall now". Through the use of the universal bond mother-son, this poem addresses the African American community and witnesses both adversity and positive adaptation strategies. Underneath, it is possible to discern the speaker's intention or, as Thomas rephrases, "the force of an utterance" (2014:2). He is the collector of history, the witness of change and the voice of tomorrow.

The use of voice is a distinctive device that Hughes displays to address the conflict between reality and utopia. By means of a natural conversational tone and direct speech, Langston Hughes favours the use of the first and the second person singular, 'I' and 'you'. His aim is to voice the struggle and become a sort of guardian of history as well as the treasurer of hope. He shows a tendency to use the "I" pronoun to identify with an experience of oppression, as in "Mother to Son". Also in "I, Too", first published in Survey Graphic in 1925, he relates different forms of adversity from an inclusive and assertive perspective, thus nullifying any possibility of contestation, as the following lines illustrate:

I am the darker brother.

They send me to the kitchen

When company comes,

But I laugh,

And eat well,

And grow strong. (Rampersad 1995: 46)

Already at this early stage, Hughes' poem "To Certain Intellectuals", first published in Messenger in 1925, bluntly expresses the duality between adversity and positive adaptation, using the first person singular for self-identification with adjectives such as "poor", "black", "ignorant", "slow". On the contrary, he uses a "you" to establish an emotional distance with those who do not meet those attributes 


\section{Alba Fernández Alonso y María Amor Barros del Río}

altogether, and he does that by means of repetition of the verse "You are no friend of mine" (Rampersad 1995: 43).

To illustrate the complexity of post-trauma reactions, the poems published at this first stage also offer paths for healing and means of positive adaptation. Resistance is a frequent attitude that allows him and his people to overcome adversity. In "Red Roses", first published in Poetry in 1926, he affirms "I'm waitin' for de springtime" (Rampersad 1995: 83-84), and in "Hey!, Hey!", published in FCTTJ, he hints at a change of attitude beyond resignation in the following verses:

I could be blue but

I been blue all night long. (112)

In general terms, the use of the pronoun "You" tends to be accompanied by the imperative form of the verb to indicate ways to overcome adversity. In "Dreams", first published in World Tomorrow in 1923, Hughes calls for hope: "Hold fast to dreams" (Rampersad 1995: 32), and a similar tone is detected again in "Mother to Son" with the line: "Don't you fall now" (30). In “The Dream Keeper”, first published in Survey Graphic in 1925, the author urges those who actively believe in change, the ones he calls "the dreamers", to pursue their hopes while he offers himself as the keeper of their aspirations. In this poem, Hughes sets forth his mission as the guardian of those precious but still weak dreams that need protection, symbolized in the following metaphor-filled stanza:

Bring me all of your dreams,

You dreamers,

Bring me all your

Heart melodies

That I may wrap them

In a blue cloud-cloth. (Rampersad 1995: 45)

There is a noticeable scarcity in the use of the collective pronoun "we", that can be found in poems such as "Justice", first published in Amsterdam News in 1923, and in "Shadows", "Afraid", "Youth" first published in Crisis, in 1923, 1924 and 1924 respectively.

Langston Hughes is also the poet of ordinary situations for his aim is to reach the black masses, as Rampersad affirms: "He was prepared to write 'down' to them" (1995: 5). This might have been the reason why his particular poetic representation of daily existence has not always been well received. His style has been defined as "far too simple and unlearned" (3), a matter much contested and more accurately typified later as "the illusion of simplicity" (Harper and Hughes 1996: 1). In any case, Langston Hughes's aesthetics of simplicity typifies his writing (Ford 1992) by means of clarity in language and down-to-earth topics. The poem "Red Roses" 
(Rampersad 1995: 83) is an appropriate example of where these two devices converge. With a profusion of metaphors, the poet awaits the "Sweet, sweet springtime", a future full of blooming flowers such as "de tulips" and "de roses red" that will make the present-day suffering worth living. These are the hopes that sustain his resilience against "de winter" and "de snow". Despite the metaphorical nature of "Red Roses", or maybe to soften it, this simple but encouraging message is accompanied by the use of very colloquial language that mirrors the oral culture of the African American community. Suppression of letters, as in "I'm waitin", and shortening of words, as in "Un'neath", are also frequently used in other poems where oral speech is purposely reproduced, as in the following verses of the poem "Hey! Hey!":

Sun's a risin',

This is gonna be ma song. (112)

In the poem "Mother to Son", Hughes reclaims "the use of dialect by black poets" (Rampersad 1995: 30) replicating the oral speech so well known to the poet. Particularly striking are the following verses:

I'se been a-climbin'on,

And reachin' landin's,

And turnin' corners,

And sometimes goin' in the dark

Where there ain't been no light. (30)

Through these lines the author seeks to naturalize a message so that it is openly received by his target audience. At the same time, this device helps to underpin Hughes as a "folk poet" (Rampersad 1995: 4). In sum, the familiarity infused in the tone of speech adds credibility and trust, two coping mechanisms that ally with tradition and contribute to resilience.

The distinctive use of language found in the selected poems also contributes to fix resilience as a means of overcoming difficulties. Linguistically, the author concentrates on two main semantic fields that oppose each other, one related to serious risk experiences, and another related to a relatively positive psychological outcome. These two opposites can be organized under the concepts 'shadows' and 'light', the former referring to negative experiences and the latter expressing the poet's hopes and means of coping. Examples of the first group might include expressions such as "heavy shade" and "stifling air" (in "Shadows"), "the too rough fingers" (in "The Dream Keeper"), "my fist is clenched" (in "Militant"), "winter winds" and "strip their body bare" (in "Stars"), "I'm weary, weary, Weary as I can be" (in "Lonesome Place"), "Because we are alone" and "And we're afraid" (in "Afraid"), "broken-winged bird" and "barren field" (in 


\section{Alba Fernández Alonso y María Amor Barros del Río}

"Dreams"). They serve to identify the multiple forms that adversity can take on and how the poet's people have endured them.

But the poet's positive nature and his firm conviction that his role is that of the recipient of his people's dreams are also present in the form of expressions such as: "tomorrow bright before us" (in "Youth"), "heart melodies" (in "The Dream Keeper"), "Sweet, sweet springtime" (in "Red Roses"), "a thousand lights of sun" (in "As I Grew Older"), “a bonze vase" and "a round fountain" (in "Dreamer"), together with positive and active verbs such as "we march" (in "Youth"), "I laugh" (in "I, Too"), "we must find the sun" (in "Shadows"). In light of this, the reader finds comfort and hope, and his resilient nature is attested to by "his capacity to endure and prevail over ill" (Miller 2015: 4). Moreover, Langston Hughes is apt to use some linguistic features that serve to reinforce the mentioned imagery so particular to the poet. He uses repetition of lines to stress some key messages, such as "You are no friend of mine" (in "To Certain Intellectuals") and "Life for me ain't been no crystal stair" (in "Mother to Son"), as well as personifications, as in "the too rough fingers of the world" (in "The Dream Keeper"), and similes, and metaphors as in "Bright like a sun- My dream" (in "As I Grew Older") or "life is a broken-winged bird" (in "Dreams").

Through a masterful use of African American speech and life experience, Hughes's ultimate purpose is to voice the different forms of oppression suffered by his people. At this early stage of his career, adversity can only be healed by holding on to the dreams of a better future, as the poem "Dreams" typifies. The resilient attitude shown by Langston Hughes takes the form of repetition in the following lines of the poem "Mother to Son":

For I'se still goin', honey,

I'se still climbin'. (Rampersad 1995: 30)

These words epitomize the tireless spirit of the African American community.

\section{Conclusion}

According to the evidence detected in his early poetry and the sociohistorical and cultural circumstances that surrounded it, Langston Hughes can be taken as an example of resilience in the face of adversity. His representation of resilience comprises both adversity in the form of the hardship experienced by the author and his people, and positive adaptation, in the form of the social competence he displays to overcome those adverse circumstances. Through the use of assorted linguistic mechanisms, such as the use of the metaphors, the assertiveness of the tone of his speech, his use of opposites to exemplify change, and the repetition of 
lines, among other devices, Hughes succeeds at portraying a true and vivid testimony of the struggle of the African American in the Unites States of the 1920s with a spirit of endurance, strength, hope and resilience.

The poems selected witness and contest the problem of racial segregation. The concepts of adversity and positive adaptation gain special importance as they furnish evidence of the injustice and oppression experienced by the author and his peers. A combined analysis of the poetic devices used by the author illustrates how adversity and positive adaptation are reflected in the tone of speech of his poems, his use of voice and the semantic fields that characterize his lines. Equally, the emergence of resilience springs from both the protective factors linked to the African American culture, racial socialization and social support networks, and the author's innate optimism and energy. The merging of the two diminishes the gravity of problems and develops coping mechanisms that respond to stressful events. Thus, in Langston Hughes's early poetry, resilience becomes the poet's tool to overcome those challenges. As a result, realism and idealism merge as a means of setting the hardship and injustice endured by the Negro in America against the recurring and long-lasting dream of a better future. In fact, it is this realism that makes the poet reach the hearts of the common people by firmly planting an idea of a better tomorrow in their minds that would make them cling to hopes and save them from going to pieces. This proves the rich and thoughtprovoking correlation between literature and psychological resilience in Hughes's poetry and helps us understand particular parts of the whole human experience and the way they are related (Moghaddam 2004). Furthermore, in the light of this work, the relationship between these two bodies of independent research, literature and psychology, is very close, as both constitute the foundations of the human psyche and shed some light on why humans behave the way they do. Adopting this approach in the study of Hughes's art in the period 1920-1930 clears up some of his concerns about racial discrimination, and guides us deeper into his motivations and his whys and wherefores as a writer. This new optic substantiates Langston Hughes as the poet of resilience amid the adversities and dreams that the African American community experienced at the dawn of the New Negro Renaissance.

\section{Notas}

1 It is interesting to clarify the difference between resilience and coping because too often these two concepts have been misused. Resilience refers to the way an issue is assessed, whereas coping alludes to the mechanisms employed after a stressful event, resilience tending to bring a positive response while coping can bring both positive and negative reactions. For further clarification, read Fletcher and Sarkar (2013). 
2 It should be noted that this resilient attitude was not only present in Hughes's works. Other leading voices of the Harlem Renaissance such as Zora Neale Hurston and Countee Cullen also explored this human dynamic in their production. The deep understanding of the black folklore that Zora Neale Hurston developed as an anthropologist led her to understand the souls of the black individuals in different environments. From her observations, she inferred a resilient attitude which in combination with humor, imagination and wisdom among others was "what inspired the being-ness of black people" (Plant 2007: 53). As evidenced in her essay "How It Feels to Be Colored Me", Hurston's commitment not to feel "tragically colored" (1928: 215) emerges in the face of hardship and takes shape in a resilient frame of mind. Countee Cullen, however, resorted to his African heritage to empower the black individual. Highly influenced by Garvey, he "proceeded to create for himself and his scorned black brethren a royal and even imperial African ancestry" (Wagner 1973: 316) as shown in "The Ballad of the Brown Girl" (1927). There is much in the history of the Harlem Renaissance yet to be analysed that deserves further scholarly attention.

3 Although slavery and its appalling impact even after its abolition are recurring topics in Hughes's work, his early poetry does not exploit these issues to their fullest extent. It will be later, in poems such as "The Negro Mother" (1931), "Let America be America Again" (1943), "Freedom's Plow" (1943) or "Slave Song" (1949), among many others, that Hughes explores the enduring imprint of slavery, a phenomenon more recently conceptualized by Saidiya Hartman, the effects of which are "skewed life chances, limited access to health and education, premature death, incarceration, and impoverishment" (2007: 6).

\section{Works Cited}

BLock, Jeanne H. and Jack BLock. 1980. The Role of Ego-Control and Ego Resiliency in the Organization of Behavior. New Jersey: Erlbaum.

Bogar, Christine and Diana HuLSE-KILLACKY. 2006. "Resiliency Determinants and Resiliency Processes among Female Adult Survivors of Childhood Sexual Abuse". Journal of Counseling and Development 84 (1): 318-327.

Bonanno, George A. 2004. “Loss, Trauma and Human Resilience: Have we Underestimated the Human Capacity to Thrive after Extremely Aversive Events?" American Psychologist 59 (1): 20-28.

Bonilla-SILVA, Eduardo. 2003. Racism without Racists: Color-blind Racism and the Persistence of Racial Inequality in America. London: Rowman and Littlefield.

Bowen-Reid, Terra L. and Jules P. Harrell. 2002. "Racist Experiences and Health
Outcomes: An Examination of Spirituality as a Buffer". Journal of Black Psychology 28 (1): 18-36.

Breslau, Joshua, Sergio Aguilar-Gaxiola, Kenneth S. Kendler, Maxwell Su, David Williams and Ronald C. KeSSLER. 2006. "Specifying RaceEthnic Differences in Risk for Psychiatric Disorder in a USA National Sample". Psychological Medicine 36 (1): 57-68.

Bryant-Davis, Thema and Carlota Ocampo. 2005. "Racist Incident-Based Trauma". The Counseling Psychologist 33 (1): 479-500.

Burstow, Bonnie. 2003. "Toward a Radical Understanding of Trauma and Trauma Work". Violence against Women 9 (1): 1293-1317.

CAmpbell-Sills, Laura, Sharon L. Cohan and Murray B. StEIN. 2006. “Relationship of Resilience to Personality, Coping, and Psychiatric Symptoms in Young Adults". Behaviour Research and Therapy 44 (1): 585-599. 


\section{Resilience as a Form of Contestation in Langston Hughes' Early Poetry}

Caughy, Margaret O'Brien, Patricia J. O'CAmpo, Suzanne M. Randolph and Kim Nickerson. 2002. "The Influence of Racial Socialization Practices on the Cognitive and Behavioral Competence of African American Preschoolers". Child Development 73 (1): 1611-1625.

ChINITZ, David. 1997. “Rejuvenation through Joy: Langston Hughes, Primitivism, and Jazz". American Literary History 9 (1): 60-78.

Clauss-Ehlers, Caroline. S. 2008. "Sociocultural Factors, Resilience, and Coping: Support for a Culturally Sensitive Measure of Resilience". Journal of Applied Developmental Psychology 29 (1): 197-212.

Cullen, Countee. 1927. The Ballad of the Brown Girl: An Old Ballad Retold. New York: Harper.

Davydov, Dmitry M., Robert SteWart, Karen Ritchie and Isabelle ChAUdieu. 2010. "Resilience and Mental Health". Clinical Psychology Review 30 (1): 479-495.

Du BoIs, William E. B., Booker T. Washington and James W. Johnson. 1965. Three Negro Classics. New York: Avon Books.

EYERMAN, Ron. 2001. Cultural Trauma: Slavery and the Formation of African American Identity. Cambridge: Cambridge U.P.

FEAGIN, Joe R. 2010. Racist America: Roots, Current Realities, and Future Reparations. New York: Routledge.

FletCher, David and Mustafa SARKAR. 2013 "Psychological Resilience: A Review and Critique of Definitions, Concepts, and Theory". European Psychologist 18 (1): 12-23.

Ford, Karen J. 1992. “Do Right to Write Right: Langston Hughes's Aesthetics of Simplicity". Twentieth Century Literature 38 (4): 436-456.

Gu, Qing and Christopher DAY. 2007. "Teachers' Resilience: A Necessary Condition for Effectiveness". Teaching and Teacher Education 23 (1): 1302-1316.

HARPER, Donna A.S. and Langston Hughes. 1996. Not So Simple: The Simple Stories by Langston Hughes. Missouri: University of Missouri Press.

Hartman, Saidiya. 2007. Lose Your Mother: A Journey Along the Atlantic Slave Route. New York: Farrar, Straus and Giroux.

Huggins, Nathan I. 2007. Harlem Renaissance. New York: Oxford U.P.
Hughes, Langston. 1926. "The Negro Artist and the Racial Mountain". The Nation 122 (1): 692-694.

Hughes, Langston. (1940) 1993. The Big Sea. New York: Hill and Wang.

Hurston, Zora N. 1928. "How It Feels to Be Colored Me". The World Tomorrow 11 (5): 215-216.

JACKSON, Debra, Angela FIRTKO and Michel Edenborough. 2007. "Personal Resilience as a Strategy for Surviving and Thriving in the Face of Workplace Adversity: A Literature Review". Journal of Advanced Nursing 60 (1): 1-9.

Karlsen, Saffron and James Y. NAZroo. 2002 "Relation between Racial Discrimination, Social Class, and Health among Ethnic Minority Groups". American Journal of Public Health 92 (1): 624-631.

KIDD, Sean and Golan ShahAR. 2008. “Resilience in Homeless Youth: The Key Role of SelfEsteem". American Journal of Orthopsychiatry 78: 163-172.

Kwate, Naa Oyo A., Heiddis B. Valdimarsdottir, Juan S. Guevarra and Dana H. BovbJerg. 2003. “Experiences of Racist Events are Associated with Negative Health Consequences for African American Women". Journal of the National Medical Association 95 (1): 450-460.

LOCKE, Alain. (1925) 1997. The New Negro: Voices of the Harlem Renaissance. New York: Touchstone.

LUTHAR, Suniya S. 2006. "Resilience in Development: A Synthesis of Research across Five Decades". Developmental Psychopathology 3 (1): 739-795.

LUthar, Suniya S. and Dante Cicchetti. 2000. "The Construct of Resilience: Implications for Interventions and Social Policies". Development and Psychopathology 12 (1): 857-885.

McCord, Colin and Harold P. Freeman. 1990. "Excess Mortality in Harlem". New England Journal of Medicine 322 (1): 173-177.

MllleR, David B. 1999. "Racial Socialization and Racial Identity: Can they Promote Resiliency for African American Adolescents?" Adolescence 34 (1): 493-501.

Miller, David B. and Randall Maclntosh. 1999. "Promoting Resilience in Urban African 


\section{Alba Fernández Alonso y María Amor Barros del Río}

American Adolescents: Racial Socialization and Identity as Protective Factors". Social Work Research 23 (1): 159-170.

MilleR, R. Baxter. 2015. The Art and Imagination of Langston Hughes. Kentucky: University Press of Kentucky.

MoghadDam, Fathali M. 2004. "From 'Psychology in Literature' to 'Psychology is Literature': An Exploration of Boundaries and Relationships". Theory and Psychology 14 (4): 505-525.

ONWUCHEKWA, Jemie. 1977. Langston Hughes: An Introduction to the Poetry. New York: Columbia U.P.

PLANT, Deborah. 2007. Zora Neale Hurston: A Biography of the Spirit. Westport: Praeger.

Rampersad, Arnold. 1995. The Collected Poems of Langston Hughes. New York: Knopf.

RAMPERSAD, Arnold. 2002. The Life of Langston Hughes. Vol. II, 1941-1967, I Dream a World. New York: Oxford U.P.
THOMAS, Jenny A. 2014. Meaning in Interaction: An Introduction to Pragmatics. New York: Routledge.

Tracy, Steven C. 2004. A Historical Guide to Langston Hughes. Oxford: Oxford U.P.

TugAde, Michele M. and Barbara L. Fredrickson. 2004. "Resilient Individuals Use Positive Emotions to Bounce back from Negative Emotional Experiences". Journal of Personality and Social Psychology 86 (1): 320333.

Utsey, Shawn O., Mark A. Bolden, Yzette Lanier and Otis Williams. 2007. "Examining the Role of Culture-specific Coping as a Predictor of Resilient Outcomes in African Americans from High-risk Urban Communities". Journal of Black Psychology 33 (1): 75-93.

WAGNER, Jean. 1973. Black Poets of the United States: From Paul Laurence Dunbar to Langston Hughes. Urbana: University of Illinois Press.

Williams, David R., Harold Neighbors and James S. JACKSON. 2003. "Racial/Ethnic Discrimination and Health: Findings from Community Studies". American Journal of Public Health 93 (1): 200-208.

Zautra, Alex J., Lisa M. Johnson, and Mary C. DavIS. 2005. "Positive Affect as a Source of Resilience for Women in Chronic Pain". Journal of Consulting and Clinical Psychology 73 (2): $212-220$.

Received: $20 / 04 / 2018$

Accepted: 28/01/2019 